\title{
МОГУЋНОСТИ РЕКОНСТРУКЦИЈЕ СРПСКОГА РАЗГОВОРНОГ ЈЕЗИКА У СЛАВЕНОСРПСКОЈ ЕПОХИ
}

\begin{abstract}
У раду се указује на теоријско-методолошка ограничења која спречавају ваљану реконструкцију разговорног језика у славеносрпској епохи. Она произлазе из недостатака јединих релевантних текстова из 18. и 19. в. (дијалога у књижевним делима, дијалога у разговорницима и филолошких расправа и граматика), а који су узроковани актуелном језичком ситуацијом и поетичким начелима стилских формација.

Кључне речи: разговорни језик, говорни језик, народни језик, колоквијализам, дијалог, разговорник, језик комедије.
\end{abstract}

1. Терминолошка разграничења у дијахронијској србистици. Појам и термин разговорни језик отварају бројна теоријско-методолошка питања, о којима нас информише чак и површни увид у лингвистичке терминолошке речнике и основну литературу. У србистици разграничавање између термина разговорни, колоквијални и говорни језик није ни доследно ни стабилизовано јер између ових термина и има и нема синонимског преклапања, а различити аутори овим терминима дају и различито значење. ${ }^{1}$ У односу на истраживања посвећена савременом језику, још је компликованија слика у дијахронијској србистици, пре свега због магловитости распрострањеног термина народни језик, који се појављује као конкурентан наведеним терминима. ${ }^{2}$ Термин $н а$ родни језик, одомаћен у србистици и под утицајем терминолошких решења у руској славистици у 19. и 20. в., овде постаје хипероним за дијалекте, али се њиме неретко описују и говори у градским срединама (као у случају описа генезе и функционисања славеносрпског језика на простору данашње Војводине). ${ }^{3}$ Урбана средина описује се као „градска”, али и као „грађанска”

\footnotetext{
*aleksandar.jus@gmail.com

${ }^{1}$ УП. податке које наводе Симеон 1969 и СХJ 1972.

2 Термин народни језик био је прихваћен и устаљен и у књижевној историји. Уп. нпр. дела Јована Скерлића у којима описује српску књижевност у 18. и 19. в.

${ }^{3}$ УП. нпр. Суботић 1989: 5. В. коментаре везане за овај термин у Гутков 2005: 62-63.
} 
(Јерковић 1972: 285), а издвајају се углавном њене лексичке специфичности. О „народним речима” и „народним пословицама” као типичним репрезентима народног језика у књижевном тексту писао је већ Милован Сучевић (1914: 6-7) у првој студиозној анализи Доситејевог језика, што указује на нови методолошки проблем: да се под народним језиком није подразумевао само скуп дијалеката већ и фолклорни језик, што ни у новијој литератури неретко није разграничено.

Терминолошка слика постаје још сложенија детаљима уколико се у обзир узме и неустаљена терминологија коју су користили српски филолози у 18. и 19. в. (уп. Мацановић 2018). Образлажући, на пример, свој избор између термина општи језик и прост језик и увиђајући пејоративне конотације другог, Јован Хаџић писао је у форми дијалога: „Сл. Зашто обштегъ, а не простогъ? Я не знамъ, шта є простъ єзыкъ, само знамъ, да онимъ истимъ говори и простъ и непростъ; нити има какавъ други, кои би се овомъ противоставити могао: дакле се пре може обшти єзыкъ назвати, него простъ, да се одъ особитогъ, коимъ само гдикои говоре, може разликовати."4 Особити језик, према сажетом Хаџићевом опису, могао би бити дијалекат, али и поједине форме социолеката. Иако је Хаџић тврдио да постоји само један општи језик којим „говори и прост и непрост”, Михаило Стевановић (1964: 29), описујући језик Захарија Орфелина, Емануила Јанковића и Павла Соларића, констатује социјално раслојавање: „Али се у пракси ови писци, сем последњег, нису ни наслањали на простонародни; већ на језик 'изображеније класе'.”

2. Могућност реконструкције разговорног језика. Није чудо што ниједан историчар српскога књижевног језика у својим расправама није дубље покретао питања разговорног језика јер би у таквим анализама заправо непрекидно измицао објект истраживања. ${ }^{5}$ Наиме, сваки текст који би се могао посматрати као „одраз” некадашњег разговорног језика у писаном изразу немогуће је упоредити са оригиналом, односно са тонским записом разговора. ${ }^{6}$ Стога смо осуђени на нужну теоријско-методолошку омашку: да уверљивост некадашњег опонашања разговорног језика анализирамо и вреднујемо узимајући мерила постављена на основу анализа савременога српског језика, базирана на описима и анализама тонских записа снимљених разговора (уп. нпр. Половина 1987). Анахроничност таквог поступка не морамо доказивати.

Стога су у србистици и даље изазовна питања како и колико можемо реконструисати разговорни језик у прошлости, и на основу којих текстова. За тзв. „предвуковски период”, као и за друге из српске историје, ова питања се морају сагледати и из угла дијахронијске стилистике, полазећи од појмова стил и жанр. Увид у текстове из друге половине 18. и прве половине 19. в. указује да некадашњи разговорни језик можемо покушати да реконструише-

\footnotetext{
${ }^{4}$ Наведено према Суботић 1989: 11. Хаџићевом термину опити језик по обиму тј. захвату ближи се савремени термин просечни језик, чији је творац био Јован Кашић (1969).

${ }^{5}$ Семантичку опозицију између термина говорни језик и разговорни језик у овом раду поистовећујемо са опозицијом говор : разговор.

${ }^{6}$ Значајан помак дијахронијска србистика добила је преоријентацијом анализе са језика на текст који се посматра као конкретна манифестација језика, покренутом монографијом Ане Кречмер (1989).
} 
мо на основу три врсте извора: а) књижевних текстова у којима се тежило миметичности, б) тзв. разговорника, в) некадашње филолошке литературе. Што се дубље иде у прошлост, реконструкција разговорног језика све је релативнија будући да је више него ретка била потреба да се прецизно и верно запише и опише неформални, спонтани разговор из животне свакодневице.

3. Два смера стварања славеносрпског језика. Настанак славеносрпског језика директна је последица српске језичке ситуације у 18. в., створене на барокној поставци о триглосији, као и односа између ниског, средњег и високог стила у њој. Како је средњи стил, односно славеносрпски језик, настајао укрштањем особина високог стила (рускословенског језика) и ниског стила („народног језика”), од почетака истраживања су се постављала питање које особине „народног” тј. „говорног језика” су продирале у рускословенски језик, када и како. Првобитна поставка о „вернакуларизацији” (србизацији, посрбљавању) рускословенског језика успостављена је истраживањима Александра Младеновића, који је доказао да је славеносрпски језик „од свога почетка био усмерен и отворен према српском народном језику” (Младеновић 2008: 197), а његова „србизација” је вршена „помоћу језичких особина данашњег екавског шумадијско-војвођанског дијалекта" (Младеновић 2008: 195-196). Овај смер развитка детаљно је описиван у радовима аутора из новосадске школе (А. Албијанић, Ј. Јерковић, Ј. Кашић, П. Херити, Љ. Суботић, J. Нуорлуото). ${ }^{8}$ Другачији смер настанка славеносрпског језика, везан за стилско уздизање „народног језика”, остварен углавном у Црној Гори, управо се описује кроз нова истраживања Исидоре Бјелаковић (2019а, 2019б).

3.1. У радовима наведених аутора термин говорни језик употребљава се веома опрезно, док термина разговорни језик нема. На пример, када се Орфелин у чувеном предговору Славеносрпског магазина (1768) позивао на „Книге на собственномъ своемъ (т. е. съ коимъ говоретъ) езыку”, ову конструкцију Младеновић (2008: 185) одређује на следећи начин: „Поменути Орфелинов сопствени језик, тј. говорни језик појединих европских народа, за Србе би - иако у томе нису сви сагласни - наравно, требало да буде српски језик или славенос(е)рпски језик како се још онда а нарочито касније често звао, или наш језик како га Орфелин назива на једном месту у предговору овога свога часописа". Младеновићево увођење термина говорни језик у овом цитату није даље праћено објашњењем, али се из анализе види да се он поистовећује с термином народни језик. ${ }^{9}$ Тако је, уосталом, било у читавом Младеновићевом опусу: у монографији О народном језику Јована Рајића он констатује да

\footnotetext{
${ }^{7}$ Појам свакодневице, значајан за тумачење разговорног стила и разговорног језика, описан је у стилистици у Симић/Јовановић 2002.

${ }^{8}$ Исти смер анализирали су и Никита Толстој (2004: 130-134), Владимир Гутков (2005: 61), Александар Албијанић (2010: 64-71) и др.

${ }^{9}$ Стихови песме „Плач Сербији” написани су „српским народним језиком”, али са неизбежним славенизмима (Младеновић 2008: 187); Аритметика Василија Дамјановића написана је „У великој мери српским народним језиком уз употребу, нарочито у предговору, и славенизама” (Младеновић 2008: 191); Рајић штампа Катихизис „на српском народном језику уз употребу, наравно, и појединих славенизама” (Младеновић 2008: 192), и сл.
} 
се у писаном виду тадашњег књижевног језика „региструју у извесној мери и типичне особине говорног језика" (Младеновић 1964: 9).

3.2. Термин „народни језик” је за Јована Кашића подразумевао и фолклорни и говорни језик. Говорни језик, у жељи за прецизнијим описом, именује и као „живи народни говор”, који илуструје конструкцијама „које су или готове преузете из народног језика, или су рађене по узору на живи народни говор" (Кашић 1968: 144-145). ${ }^{10}$ Иако не уводи термин разговорни језик, Кашић (1968: 145) о њему говори кроз опис дијалога Видаковићевих јунака: „Не само да су Видаковићеви јунаци употребљавали устаљене изразе које налазимо и у народном језику него су често и говорили онако како су разговарали Видаковићеви савременици. Ако у тим разговорима и нађемо неку рускословенску реч или облик, то не мења саму суштину дијалога који је потпуно у народном духу.” Наведени цитат показује да маркере разговорног Кашић (1968: 145) препознаје првенствено у разговорним фразеологизмима и устаљеним изразима, али и у „употреби појединих речи и израза који су особина говорног језика, у првом реду примитивнијих средина": море, бре, богме, речце та и $e$ „у почетку говора”, вокативи синко и сине и сл. Такође, на другом месту у монографији Кашић (1968: 111) указује и на синтаксичке „краће конструкције” у дијалозима „који су често преношење живе говорне речи у писане текстове". Иако је прецизно детектовао одређене особине разговорног језика, Кашић (1968: 145) у закључку ипак промашује стилистичку суштину, сматрајући да се у њима „у извесној мери” огледа „неизграђеност књижевног језика", а не наглашавајући Видаковићеву жељу да актуелизује говор својих јунака и ликова. Није помогло ни што је претходно на истом месту овај Видаковићев језички поступак повезао и са ширим стилским контекстом дијалога: „Често се разговори који одговарају говорном језику воде у помало шаљивом тону".

3.3. У Доситејевој аутобиографији и Баснама, регистровала је Херта Куна (1970: 170), реченица је „ne samo znatno kraća i razumljivija nego i veoma živa i po strukturi bliska rečenici narodnih pripovijedaka". Појам живог опет се, као и код J. Кашића, везује и за фолклорни и за народни језик, тј. дијалекат: „Osim toga, i kod Dositeja ima dosta često rečenica sa elipsom predikata, što je jedna od osobina sremskog govora" (Куна 1970: 170). Описујући Доситејеву лексику, Куна (1970: 252) уводи и термин колоквијални језик, сматрајући да су турцизми по правилу његов саставни део, „koji je ušao u Dositejeve spise pod neposrednim impulsom želje da se što više pribiži govoru naroda".

3.4. За Питера Херитија (1983), аутора монографије Кюижевни језик Емануила Јанковића, говорни језик и народни језик прави су синоними. ${ }^{11} \mathrm{OH}$ у закључку на више места говори о Јанковићевом „народном језику” (Херити 1983: 311), док тај израз Маринковић (1966: 529) описује као језик „близак или, чак, идентичан обичном говору краја из којег је водио своје порекло. Појам говора прецизиран је, дакле, атрибутом обичан. За Никиту Толстоја

\footnotetext{
${ }^{10}$ Примери: ако ти је живот мио, никуд ни маћи, но камо та срећа, једно другому до ува и сл.

${ }^{11}$ Уп. опис деловања писаца „који су такође веровали у могућности једног књижевног српског језика проистеклог из говорног, односно народног” (Херити 1983: 6).
} 
(2004: 122, 123) у Јанковићевом препеву Терговаца чува се (у преводу на српски језик) ,аналогни прост разговорни језик”, што се потом значајно терминолошки прецизира: „Може се говорити о томе да је у преводима Е. Јанковића доследно спроведен типично разговорни стил језика, по свој прилици војвођански градски коине.” Термин градски коине, нажалост, у дијахронијској србистици још увек није довољно теоријски разрађен.

4. Разговорни језик у граматикама и језикословним расправама. Почетак 19. в. довео је, кроз интересовања за реформу ћирилице, и до ближег интересовања за фонетске црте говорног језика. Расправе Павла Соларића, Саве Мркаља и Вука Караџића упознају Србе и са начелом „пиши као што говориш", које у оба своја тумачења вуче ка српском народном тј. говорном језику. ${ }^{12}$ Несумњиво је да је Вук ово начело увек везивао за говор, и то говор народа. Запажа се и Вукова еволуција у тумачењу значења Аделунговог (потом Соларићевог и Мркаљевог) начела од оног уско правописног па до оног схваћеног у ширем књижевнојезичком контексту. У почетку то је ортографски принцип: „Пак зашто да се ръчи изврћу, и да се другчіе пишу него што се говоре? (Караџић 1968: 17); „но наїпосле ми се учинило да їе овако наїлагше дотерати Сербско Правописанье под оно заглавлье: Пиши, као што говориш; а читаї, као што їе написано (Караџић 1968: 31). Међутим, већ у Вуковој Другој рецензији српској читамо савет: „проды се поправляня езыка ; него пиши, као што народъ говори, па ако не узваля, не ћешъ ты быти кривъ, него народъ, као и у свима осталымъ (како старымъ, тако и новымъ) езыцима" (Караџић 1968: 195). Критеријум као што народ говори, који први пут у српској култури постаје средишњи, не подразумева у новом Вуковом тумачењу само фонетску страну израза, већ комплетну језичку структуру. ${ }^{13}$ Све до Вукове Писменице (1814) и Српског рјечника (1818), праћеног Српском граматиком, ми, нажалост, немамо детаљније филолошке описе српског „народног” језика, па зато и одговор на загонетку говорног и разговорног језика, нарочито многих њихових синтаксичких и прагматичких особина, остаје већим делом у магли. Управо је питање инвентара графема у српској ћирилици, те првенствено статуса графема $<\mathrm{x}>,<\phi>$, и $<$ џ $>$, утицало на веће занимање не само филолога за говорни језик, нпр. и у делу Луке Милованова Георгијевића. У средишту интересовања нашла се тада и она фонетска страна говорног језика која свој одраз није налазила директно у инвентару писма:

Србльи говоре у брзомъ изговору рашта, мешчини, ништъ, валь да, госпръ, приль, ча (приль и ча найвише по Бачкойн. п. приль Іова, ча Пая) и т. д. мъсто ради шта, мени се чини, ништа, валяда, господаръ, прїятель, чича ; али тркъ, крвъ, гркъ, трнъ, дрво, грмъ и т. д. они тако изговараю, макар иза гласа выкали, или на уво еданъ другомъ шаптали (Караџић 1968: 191).

\footnotetext{
${ }^{12}$ Обично се ово начело тумачи у контексту залагања за фонолошки (фонетски) правопис ослоњен на црте народног језика, али и у значењу „' piši kao što misliš', tj. kako je u onom jeziku kojim izričeš misli” (Могуш 1987: 92).

13 „И я велимъ Србски, али како Србски? Мы велимо онако, као што народъ говори: Склоненїя, сопряженїя и Синтаксисъ (едномъ рїечи сву Грамматику) морамо узети одъ пастыра и одъ орача ; а за остало ћемо се договарати” (Караџић 1968: 191).
} 
Концепција граматике Јосифа Добровског, коју су преузимали и наши граматичари, није, међутим, погодовала описима говорног и разговорног језика јер у њој нема описа лексике и синтаксе, нарочито оне говорне, нити било каквих социолингвистичких, стилистичких или прагматичких напомена.

5. Књижевни текст и реконструкција разговорног језика. Специјални функционални стилови (научни, публицистички, административни), који су се зачињали у предстандардној епохи, само су у одређеним сегментима, пре свега лексичком и фразеолошком, могли указати на особине говорног језика. Тако, на пример, разговорну фразеологију срећемо и у тадашњим дневним новинама (Милановић 2013: 204-210), али и у првим Вуковим расправама. ${ }^{14}$ Друге особине разговорног језика стога ваља тражити пре свега у књижевним делима. Књижевноуметнички стил, као одувек отворен за утицај (раз)говорног језика, најсигурнији је извор колоквијализама. Стилистичка анализа мора водити рачуна о чињеници да су колоквијализми у књижевности - нарочито у предвуковској епохи, а и током стандардизације језика - могли бити стилски мотивисани и немотивисани: први активирани свесно, дакле као стилеме, други су пак били плод омашке, непажње, те немају стилску вредност. Јасно је да црте разговорног језика пре свега треба тражити у тадашњој драми, али су многи колоквијализми већ анализирани и у различитим жанровима прозе, нпр. у путописима. ${ }^{15}$ Снажан утицај говорног језика регистрован је и у тзв. „календарској књижевности”, алманасима, календарима и забавницима, штиву које је одређивано и као „књиге за народ” или „пучке књиге”. У „календарској књижевности” је постојала „тежња уредника и издавача да директно успоставе дијалог са народом, да остваре потпуну комуникацију са најширим слојем читалачке публике" (Матицки 1986: 32, $51)$.

5.1. У прози би колоквијализме ваљало очекивати пре свега у дијалозима књижевних јунака и ликова, на основу чега би се могла анализирати уверљивост или пак извештаченост говора, односно, изражено социолингвистичком терминологијом, говорних чинова (Радовановић 2003: 159-162). Стилска недаћа писаца епоха сентиментализма и класицизма лежала је, међутим, у чињеници да је синтакса аутентичног живог разговора препуна недовршених реченица, елипси, огрешења и сл. Тадашњи писци, свесни ових особина, разговор су ипак по правилу улепшавали „граматикализовањем”, односно пребацивањем у форму његове синтаксичке потпуности и коректности, док су аутентичност покушавали обезбедити само на фонетској и лексичкој равни, активирањем форми карактеристичних за неформалну комуникацију. Иако у дијалозима у тадашњој прози углавном има многих узвика и партикула забележених касније у Вуковом речнику, ${ }^{16}$ нема многих говорних „поштапалица”

${ }^{14}$ Уп.: „Тако дебело еръ, у осталымъ речма, остае 5тый точак у колима” (Караџић 1968: 139); „но колико га мы познаемо изъ ньговы кньига, боимосе да не рече: Слїепацъ слїепца оће да води" (Караџић 1968: 194) и сл.

${ }^{15}$ Уп. анализу стилсксих функција речи страног порекла, хунгаризама, германизама и турцизама у тадашњим путописима (Цветковић Теофиловић 2016: 29-44).

${ }^{16}$ УП. поглавља о речцама и узвицима у монографијама о језику писаца предвуковске епохе према Милановић 2014: 270-271. 
као информативно нефункционалних у књижевном тексту, из културолошких разлога нема псовки и опсцене лексике, и сл. Ређе монографије у којима се засебно у односу на језик наратора описује језик књижевних јунака показују да су писци „предвуковске” епохе дијалоге чинили лексички ближим живом разговору, тј. „свакодневном језику људи ове средине” (Јерковић 1976: 135) активирањем „варваризама” из немачког, мађарског и турског језика који дочаравају специфичности градског живота. ${ }^{17}$ Лексику страног порекла као маркере говорног језика у језику Гаврила Стефановића Венцловића већ почетком 20. в. издвојио је Владан Јовановић (1911), а у језику Доситеја Обрадовића Милан Сучевић (1914). ${ }^{18}$ Доситејев пут, као и у другим областима, и у поступку активирања говорних германизама, романизама и турцизама следио је и пуриста Павле Соларић (Бабић 2012: 207-208).

Поетичке поставке везане за миметичност у различитим стилским формацијама (сентиментализам : романтизам : реализам) у средиште интересовања на различите начине су доводиле и проблем (не)уверљивости разговора у књижевном делу, ${ }^{19}$ што би на књижевнојезичком плану водило, на пример, и ка анализи стилског статуса различитих славенизама. Питања на која је још увек јако тешко дати одговор јесу колико су славенизми били карактеристика градског (раз)говорног језика, да ли их је било и у сеоском разговорном језику на тлу данашње Војводине, и сл. Такве социолингвистичке напомене, нажалост, у тадашњој филолошкој литератури углавном немамо, осим оних које нуди Вуков Српски рјечник (1818).

Од појаве првог српског романа Аристид и Наталија (1801) па све до појаве српске сеоске приповетке у другој половини 19. в., у епохи реализма (РКТ 1992), ауторски говор се није конституисао по угледу на разговорни језик. Тек са појавом приповедања у првом лицу, у форми нараторовог ја-говора који репрезентује вуковски народни језик, а нарочито од тренутка преузимања технике сказа из руске књижевности, можемо издвајати елементе разговорног језика и у ауторском говору писаца епохе реализма. Али, већ у Видаковићевим романима, на самом почетку 19. в., аутор тежи актуелизацији говора својих јунака у дијалозима кроз активирање многих типичних маркера разговорног језика. ${ }^{20}$

5.2. Зато је веома значајно из перспективе сагледавања разговорног језика уважити запажања како тадашње књижевне критике, односно актуелно

\footnotetext{
${ }^{17}$ УП. примере у Јерковић 1972: 285-286, Јерковић 1976: 135-136.

${ }^{18}$ Сучевић (1914: 6-7) издваја турцизме (аман, атар, бака, бре, вилајет, зејман, есап, кардаш, пешкеш, терзија и шејтан) и германизме (грунт, најфајније, сапрлотирања, солдат, унтерофицир, тал, фурт и итрапаи) као речи „које су се већ биле одомаћиле у језику Срба”, а које у „сличицама из народног живота” дају „нарочиту занимљивост”.

${ }^{19}$ Методолошки опрез и овде је неопходан. Пишући о Стеријином сукобљавању књижевног и стварног света, Душан Иванић (2007: 34) подсећа: „И кад је имититативан, миметички, дух приповиједања се прилагођава општим текстуалним конвенцијама стилских норми, градње ликова и фабуле.”

${ }^{20}$ „Одређене синтаксичко-семантичко-прагматичке категорије примарно се, а неке и једино, изражавају у оквиру управног говора, као на примјер, употреба вокатива, императива, узвика, узвичних, упитних и упитно-узвичних исказа, појединих типова експресивне и емоционалне лексике и сл.” (Ковачевић 2012: 33).
} 
вредновање језика и стила у дијалозима, тако и запажања књижевне историје, односно вредновање са мање или веће временске дистанце. Будући да је настајало у време настанка романа, актуелно вредновање аутентичности књижевних дијалога за наша истраживања има неупоредиво већи значај, нарочито оно изнето у Вуковим рецензијама, првим текстовима који су репрезентовали белићевско „културно мишљење” и постали темељ будућег стандардног језика. Вук у њима полази од критеријума чистоте језика (Караџић 1968: 126), ${ }^{21}$ а као узоран за књижевика узима се чист и непокварен говор народа српскога. ${ }^{22}$ Већ у првој рецензији, романа Усамљени јуноша, Вук Караџић (1968: 130-131) указује на Видаковићеве конструкције које не постоје у говору. ${ }^{23}$ У другој рецензији, романа Љубомир у Јелисијуму, Вук Караџић (1968: 146-147) већ погађа саму суштину вреднујући уверљивост дијалога. Примери су добро одабрани, и још боље прокоментарисани. Тако Вук издваја следећи исказ из дијалога: поздравите вы Господина Бучина, да се я нъга нимало не боимъ, бяше онъ дщерь свою болъ чувао; она е тражила моега Сына, а не мой Сынь ню. У коментару овог Љубомировог исказа Вук Караџић (1968: 146-147) не критикује само дочаравање самога живог разговора, већ и дочаравање говорника и говорне ситуаиије: (- тако се одговараю зле жене - опайгоре и начжакбабе - а не Философи, као што Г. В. каже да е нБговъ Любомиръ -).

Иако не жели да похвали уверљивост опонашања разговорног језика у дијалогу и иако не наводи критеријуме по којима је одабирао цитате, Вук Караџић (1968: 147-148, 151) ипак селектује поједине дијалоге Видаковићевих јунака који (вероватно) добро дочаравају живи разговор:

a) а слуга (Архи-Епїскоповъ) рекао му: „А ель што младо?” „Младо и прекрасно двое дъчице, отвъща Светозар.” Служит. „Та не пытамъ я за дъцу, но за матерь ели млада.” Светоз. „Нїе тако ни стара, али е добра сирота.” Служит. „На часть Вам све добре на свъту, само мени доведите младу и льпу",24

б) а слуге се почеле смїяти, онда он рекао: „Бога ти, еси л’ ты заборавїо оно, што у С. писму пише, гладна наранити, жедна напоити?".25

в) а она рекла: „Яао! Ето ти ми куге, кой га бъсъ садъ овамо донесе.”26

${ }^{21}$ Вук Караџић (1968: 126) наглашава да у анализи књиге „прелазимо на чистоту єзыка, коимъ є писана".

${ }^{22}$ Будући да још немамо постојану језичку норму, вели Вук Караџић (1968: 126), српски књижевници се ,(кадъ Србски пишу) мораю владати по чистомъ и непоквареномъ говору народа Србскога”. И за писани језик, дакле, узор мора бити народни говор: „Кои Списатель Србскї грњши противъ говора свогъ народа, онай грђши противъ правила свога єзыка" (Караџић 1968 : 126).

${ }^{23}$ У исправкама Видаковићевих решења Вукове формулације су: „Србльи кажу”, „То бы Србльинъ казао”, „Србльи не кажу” (Караџић 1968: 131).

${ }^{24}$ Добро су оживљени и чести неспоразуми у разговору, али и распрострањене фонетске црте разговорног језика, кроз форму /jel/, као и карактеристичне лексеме, попут иницијалног та.

${ }^{25}$ Разговорна конструкција Бога ти и форме /jesil/ и /naraniti/ и даље сведоче о вештој актуелизацији дијалошких исказа Видаковићевих јунака.

${ }^{26}$ Уз узвик јао и речцу ето, утисак живог разговора дочарава и разговорна конструкција који га бес донесе. 
Вредан је похвале и Видаковићев напор да на фонетској (познајес, деристе, досло), морфолошкој (проклете деристе) и лексичкој равни (море) актуелизује и (из)говор странца који лоше говори српски: Младить смешетьи се: „Простите Деко, я Васъ не познаем.” „Како да ме не познаесъ море? - проклете деристе! куда оно досло!"27

Вук стално под знак питања доводи уверљивост разговорног језика у Видаковићевим дијалозима. Једно од значајних теоријских питања која покреће у првој српској књижевној критици јесте и питање језичког анахронизма, овде конкретизовано на примеру језичких етикеција (о чему говоримо у т. 6):

Есу ли се Србльи у врїеме Душаново поздравляли: Имамъ ли честь овдъ поздравити Г. Н.? Честь отъ мое стране, я самь тай. Вы сте Г. Н.? На службы, я самь. Драго ми е : на служби вашимъ благородїямъ (Караџић 1968: 175).

Полазећи од културолошких константи у патријархалном српском друштву, Вуку Караџићу (1968: 175) су, додајмо као веома значајно, потпуно неуверљиви садржај, стил и лексика Видаковићевих дијалога:

Нека Србкинъ суде, допушта ли благообразный характеръ народа нашега, да се дьевойке съ момцыма разговараю о дъвству, и о намъренїю, кое е естество имало съ ньима, кадъ їй е стварало; [...] да снаа предъ свекромъ рече „дътету дадемъ сису” и т. д.

Са друге стране, у својим ироничним коментарима, датим у заградама, Вук Караџић (1968: 151) се позива на шаљиве и ласцивне анегдоте у којима такође доминира разговорни језик: (- то е као онай што е викао: оди не ћу ти ништа, оди! а (полако) ядно ти га нећу! да ми те е уватити! -). Сводећи своју расправу о уверљивости у Видаковићевим романима, Вук износи поставку да о мотивисаности поступака књижевних јунака сведоче њихови поступци у роману, али и њихов говор. Поетичка питања тако су се све више доводила у везу са књижевнојезичким. Из те перспективе, старији Видаковићеви романи добијају вредносни примат над новим који Караџић (1968: 176) приказује, а тиме се индиректно указује и на развојни пут славеносрпског језика:

У поменутымъ романима представлясе човекъ као што естъ, и као што бы требало да буде. Ондье паметанъ и поштенъ човекъ говори и ради свагда, као паметанъ и поштенъ; будала као будала; рдьавъ и неваляо човекъ, као рдьавъ и неваляо човекъ; курва као курва и т. д. А овдье на некимъ мъстима Любомиръ и Светозаръ говоре, и раде као будале и вътреняцы и рдьави люди; Драгиня и Мелиса као курве; а Влайко и Агапїя опетъ кашто морализираю као Сократ.

5.3. Већ је Милан Решетар (1952: 1) тврдио како су комедије Марина Држића веродостојно преносиле дубровачки говор, „и властела и пучани, и мушко и женско, и старо и младо”. Уз неопходну меру методолошке уздржаности с којом смо ушли у овај рад, Решетаров суд морамо узети као теоријски ваљан: комедија јесте најадекватнији простор за настајање текста по особинама блиског разговорном језику. То у „предвуковској” епохи доказују Сте-

\footnotetext{
${ }^{27}$ На овом месту Вук Караџић (1968: 151) луцидно запажа да овакве фонетске црте више одговарају Грку него Албанцу, тј. „Албанезу”, који говори српски језик: „,а они му казали да нїе Гркъ него Албанезъ (- кадъ е быо Албанезъ, зашто е говорїо: сто е, познаесъ, окемъ и т. д.? -).”
} 
ријине комедије, које неретко имају и фолклорну подлогу (Иванић 2007: 39), или Трифковићеве комедије које у поступцима карактеризације ликова или обликовања дијалога подразумевају редукцију (Несторовић 2016: 337-338). Трифковићева сажетост може се посматрати и као разговорна компонента комедија која писцу помаже у комуникацији са публиком. Када није тежио комичним ефектима кроз карикирање говора јунака, нпр. у Покондиреној тикви, језик Стеријиних дијалога је, нпр. у Злој жени, „готово у потпуности народни и под снажним утицајем Вукових реформи” (Херити 1999: 84).

6. Текстови писани разговорним стилом. Недовољно је из угла анализе разговорног језика изучена грађа коју нуде приватна писма, као и дневници и аутобиографије у епистоларној форми (попут аутобиографије Јована Суботића), текстови који фингирају разговор, односно подразумевају комуникацију двоје или више саговорника, а писани су разговорним стилом у 18. и 19. в. За многе од њих карактеристична је наглашена фамилијарност, тј. незваничност односа, која се исказује и низом колоквијализама, али, са друге стране, на „чистоћу” разговорног језика у њима несумњиво утиче низ обавезних књишких, реторичких конвенција. Тако, нпр., у Рајићевим „приватним писмима, писмима домаће природе, упућеним Макси Секулићу и Самуилу, Рајићев језик је у највећој мери народни", што Младеновић (1964: 17) илуструје лексемама дрека, крекетање, жентурина, гр'оце, жабокречина, чор$б a$, али и „грађом реченица”, уз закључак у поглављу из синтаксе: „Важно је да ови примери Рајићевог српскохрватског језика показују, пре свега, јасност у изражавању и да у највећој мери илуструју и Рајићев говорни језик у коме се, природно, огледа народни говор Рајићевог времена” (Младеновић 1964: 135).

7. Разговорници као извор. Чини се да би драгоцен корпус за истраживање разговорног језика у славеносрпској епохи могла чинити специфична врста текстова, коју и Рајна Драгићевић (2018: 99), следећи Владимира Гуткова, назива разговорницима, а одређује их као „збирке замишљених разговора у уобичајеним комуникативним ситуацијама". Чињенице да су такви разговори на одређени начин нормирани, готово „канонизовани” у писаној форми, као и да су у доброј мери плод превода са страних језика морају створити дистанцу према њиховој аутентичности. Ово нарочито важи за сферу учтивости, нпр. удељивање комплимената, при којима су текстови прописивали засићеност лексичким славенизмима и ненародском синтаксом. Одређену дозу уверљивости текстовима прописаних комплимената давали су чести вокативи и поједине фонетске форме (изволте и сл.). С друге стране, већи број издања разговорника сведочи да су били веома популарни те да су несумњиво морали утицати на разговорни језик барем ученијег слоја Срба. Све то води претпоставци да су барем у градовима и варошима на тлу данашње Војводине разговори могли бити и поприлично извештачени у односу на „простонародне” и под утицајем литературе, што у одређеној мери показују и дијалози у комедијама, али и филолошка запажања у тадашњим радовима. ${ }^{28}$

\footnotetext{
${ }^{28}$ Тако поједине разговоре из разговорника Р. Драгићевић (2018: 104) описује на следећи начин: „Овај разговор из 1794. године вештачки је, али тако животан.”
} 
8. Закључна разматрања. Анализом текстова из славеносрпске епохе дошли смо до разочаравајућих закључака када судимо о могућности прецизне реконструкције тадашњег разговорног језика. Његову реконструкцију можемо за сада само наслутити упоређивањем података које нам нуде, по редоследу важности: а) дијалози ликова и јунака у књижевним делима (првенствено у комедијама, али и у прози); б) дијалози у разговорницима; в) филолошка литература. Оваква реконструкција унапред се суочава са многим ограничењима која спречавају да многе језичке особине славеносрпске епохе недвосмислено у тексту означимо као колоквијализме.

8.1. Чак и када их србисти наводе као уверљиве, у књижевним дијалозима лако опажамо многе неразговорне особине. На пример, иако хвали Видаковићево „преношење живе говорне речи у писане текстове”, Кашић (1968: 111) као да у примерима превиђа много књишког, од фонетских црта (тко) до реда речи (Тко си да си, докле ми се не кажеш, отоворити ти нећу; Јесте ли примили писмо моје). Насупрот примерима које хвали, Кашић (1968: 111) издваја и неуспело опонашање дијалога: „Поред дијалога ове врсте налазимо и такве који су у ствари монолози два лица. Дијалози овог типа су од мањег значаја јер у њима по правилу има далеко више рускословенских елемената." Оваква запажања, наравно, могу се уопштити за све књижевне дијалоге пре епохе реализма. Стеријине и Трифковићеве комедије нуде више грађе, али и ове дијалоге због пропратних стилских ефеката које су морали постићи морамо узети с опрезом.

8.2. Исту врсту хендикепа запажамо и у дијалозима које културолошки, па и језичко-стилски, нормирају тадашњи разговорници. Извештаченост, неприродност ових дијалога можемо претпоставити, али не и доказати. Могућност да су из литературе улазили у реалне дијалоге, нарочито у „изображенијој” средини није искључена.

8.3. И трећи извор, филолошке расправе и граматике, има значајна ограничења. У погледу сагледавања разговорног језика уочљива је недовољна информативност због актуелне језичке ситуације не само код Срба, те уобичајеног погледа на ниски стил пре Доситеја и, нарочито, пре Вука.

\section{ЛИТЕРАТУРА}

Албијанић 2010: Александар Албијанић, Прилози о српском предвуковском кьижевном језику, Београд - Нови Сад: Завод за уџбенике и наставна средства - Матица српска - Вукова задужбина.

Бабић 2012: Биљана Бабић, Ортографске и јуезичке карактеристике у штампаним дјелима Павла Соларића, Бања Лука: Филолошки факултет.

Бјелаковић 2019а: Исидора Бјелаковић, Језик докумената Архива манастира Савине (18. век), у: Српско језичко и књижевно насљеђе на простору данашње Црне Горе. Српски језик и књижевност данас: зборник радова са Другог међународног научног скупа одржаног у Подгорици 26-28. маја 
2017. године (ур. Ј. Стојановић), Подгорица: Матица српска - Друштво чланова у Црној Гори; Нови Сад: Матица српска; Бања Лука: Матица српска - Друштво чланова Матице српске у Републици Српској, 515-526.

Бјелаковић 2019б: Исидора Бјелаковић, Језик докумената Архива Српске православне епархије будимске у Сентандреји (прва половина 18. века), Научни састанак слависта у Вукове дане, 48/1, 89-101.

Грицкат 1987: Ирена Грицкат, Још нека питања у вези са славеносрпском епохом, Јужнословенски филолог, XLIII, 111-135.

Гутков 2005: Владимир П. Гутков, Славистика - србистика. Изабрани радови, Београд - Нови Сад: Завод за уџбенике и наставна средства - Вукова задужбина - Матица српска.

Иванић 2007: Душан Иванић, Огледи о Стерији, Београд: Друштво за српски језик и књижевност Србије.

Јерковић 1972: Јован Јерковић, Језик Јакова Игњатовића, Нови Сад: Матица српска.

Јерковић 1976: Јован Јерковић, Језик Богобоја Атанаџковића, Нови Сад: Матица српска.

Јовановић 1911: Владан С. Јовановић, Гаврило Стефановић Венцловић, Српски дијалектолошки зборник, II, 105-306.

Караџић 1968: Вук Стефановић Караџић, О језику и књижевности I (прир. Берислав Николић), Сабрана дела Вука Караџића, књига дванаеста, Београд: Просвета.

Кашић 1968: Јован Кашић, Језик Милована Видаковића, Нови Сад: Филозофски факултет.

Кашић 1969: Јован Кашић, Фонетске и морфолошке особине просечног језика прве половине XIX века, Годишьак Филозофског факултета у Новом Саду, XII/1, 183-212.

Ковачевић 2012: Милош Ковачевић, Стилистика типова говора у Причањима Вука Дојчевића Стефана Митрова Љубише, у: Паштровићи (језик и књижевност) (ур. Мила Медиговић-Стефановић), Београд - Петровац на мору, 15-41.

Кречмер 1989: Anna Kretschmer, Zur Methodik der Untersuchung älterer slavischer schriftsprachlicher Texte (am Beispel des slavenoserbischen Schrifttums), München: Verlag Otto Sagner.

Куна 1970: Herta Kuna, Jezičke karakteristike književnih djela Dositeja Obradovića, Sarajevo: Akademija nauka i umjetnosti Bosne i Hercegovine.

Матицки 1986: Миодраг Матицки, Библиографија српских алманаха и календара, I, Београд: Српска какдемија наука и уметности.

Мацановић 2018: Ана Мацановић, Српска језикословна терминологија у 19. веку, Београд: Институт за српски језик САНУ.

Милановић 2014: Александар Милановић, Језик Јована Суботића, Београд: Чигоја штампа - Филолошки факултет у Београду.

Милановић 2017: Александар Милановић, Језичко-стилски утицаји народних приповедака на српску прозу у 19. веку, у: Данища : српски народни 
илустровани календар за годину 2018 (ур. Миодраг Матицки и Нада Милошевић-Ђорђевић), Београд: Вукова задужбина, 191-206.

Младеновић 1964: Александар Младеновић, O народном језику Јована Рајића, Нови Сад: Матица српска.

Младеновић 2008: Александар Младеновић, Историја српског језика : одабрани радови, Београд: Чигоја штампа.

Могуш 1987: Milan Moguš, O načelu 'piši kao što govoriš' kod Vuka Stefanovića Karadžića, y: Зборник радова о Вуку Стефановићу Каращићу (одг. ур. Славко Леовац), Сарајево: РО Институт за језик и књижевност, 87-93.

Несторовић 2016: Зорица Несторовић, Велико доба : Историја развитка драме у српској књижевности XVIII и XIX века, Београд: Klett.

Половина 1987: Vesna Polovina, Leksičko-semantička kohezija u razgovornom jeziku, Beograd: Filološki fakultet.

Радовановић 2003: Милорад Радовановић, Сочиолингвистика, Сремски Карловци - Нови Сад: Издавачка књижарница Зорана Стојановића.

Решетар 1952: Милан Решетар, Најстарија дубровачка проза, Београд: Српска акдемија наука.

PKT 1992: Rečnik književnih termina (gl. i odg. ur. Dragiša Živković), drugo, dopunjeno izdanje, Nolit: Beograd.

Симеон 1969: Rikard Simeon, Enciklopedijski rječnik lingvističkih naziva, I-II, Zagreb: Matica hrvatska.

Симић/Јовановић 2002: Радоје Симић и Јелена Јовановић, Основи теорије функиионалних стилова, Београд: Јасен.

Стевановић 1964: Михаило Стевановић, Савремени српскохрватски језик, I, Београд: Научна књига.

Суботић Љ. 1989: Љиљана Суботић, Језик Јована Хаџића, Нови Сад: Матица српска.

Сучевић 1914: Миловаан Сучевић, Језик у делима Доситеја Обрадовића, Извештај Српске православне велике гимназије ср. Карловачке за школску годину 1913/14, књ. 55, Сремски Карловци, 5-60.

CXJ 1972: Srpskohrvatski jezik (red. i ured. Asim Peco i Živojin Stanojčić), Enciklopedijski leksikon Mozaik znanja, Beograd: Interpres.

Толстој 2004: Никита И. Толстој, Студије и чланци из историје српског књижевног језика, Београд - Нови Сад: Завод за уџбенике и наставна средства - Вукова задужбина - Матица српска.

Тошовић 2002: Бранко Тошовић, Функиионални стилови, Београд: Београдска књига.

Цветковић Теофиловић 2016: Ирена Цветковић Теофиловић, Језик совершени, Ниш: Филозофски факултет.

Чаркић 2002: Милосав Ж. Чаркић, Увод у стилистику, Београд: Научна књига.

Херити 1983: Питер Херити, Книжевни језик Емануила Јанковића, Нови Сад: Матица српска.

Херити 1999: Питер Херити, Језичка разматрања, Београд - Нови Сад: Завод за уџбенике и наставна средства - Вукова задужбина - Матица српска. 


\title{
Aleksandar M. Milanović \\ ON POSSIBILITIES TO RECONSTRUCT SPOKEN SERBIAN DURING THE SLAVONIC-SERBIAN PERIOD
}

\begin{abstract}
Summary
The paper explores and highlights theoretical and methodological contraints restricting a valid reconstruction of spoken language in the Slavonic-Serbian period. The constraints are due to a lack of relevant 18 th- and- 19th- century referential texts with dialogues such as dialogues in literary works, conversation- usage sourcebooks, philological debates, which all are determined by the current language situation and poetic principles of stylistic formations.

Key words: spoken language, (spoken) vernacular, people's language, colloquialism, dialogue, conversation-usage sourcebook, the language of comedy.
\end{abstract}

